\title{
Improving Instruction in Universities: A Case Study of the Ontario Universities Program for Instructional Development (OUPID)
}

\author{
MEI-FEI ELRICK*
}

\section{ABSTRACT}

In the late 1960's and 1970's, universities established programs, projects, and offices to improve the quality of undergraduate teaching. One of these, the Ontario Universities Program for Instructional Development (OUPID), was created to develop teaching in Ontario's 16 universities. It employed two methods, individual grants and institutional grants, to fulfil its mandate. The Program's limited impact on teaching was attributed to the amount of money, $\$ 2,500,000$ earmarked for OUPID during its seven years of operation (1973-80) and to the lack of a plan. When examined closely, these reasons only partially explain OUPID's limited influence on teaching. It is more illuminating to consider the Program in relation to what most academics and universities value. This reveals that OUPID's methods neither reflected the way academics view good teaching and teaching improvement nor the way the universities believe excellence is fostered. These findings suggest that interventions which seek to change university teaching must agree with and then extend academic and university values. This conclusion has implications for the response universities make as they address the recent concern for the quality of undergraduate education.

\section{RÉSUMÉ}

À la fin des années 60 et dans les années 70 , les universités ont mis en place des programmes, des projets et des services afin d'améliorer la qualité de l'enseignement dans le premier cycle universitaire. L'un de ceux-ci, le Programme de développement de l' instruction dans les universités ontariennes (OUPID: Ontario Universities Program for Instructional Development) fut créé dans le but de promouvoir l'enseignement dans 16 universités en Ontario. Pour atteindre son objectif, le programme faisait appel à deux méthodes: celle des bourses individuelles et celle des bourses institutionnelles. L'impact limité du programme sur l'enseignement fut attribué, d'une part, à l'insuffisance de la somme de 
2500000 dollars allouée à OUPID durant les 7 années d'application (73-80), d'autre part à l'absence de plan concerté. En y regardant de plus près, ces raisons n'expliquent que partiellement l' influence du plan OUPID sur l'enseignement. Il est plus éclairant de considérer le programme par rapport à ce que beaucoup d'universitaires et d'universités préconisent avant tout. Il en ressort que les méthodes d'OUPID ne reflètent ni la façon dont les universitaires envisagent un bon enseignement et son amélioration, ni la façon dont les universités estiment que la qualité est favorisée. Ces résultats suggèrent que les interventions visant à modifier l'enseignement universitaire doivent s'accorder et donc s'étendre aux valeurs scolaires et universitaires. Cette conclusion a des répercussions sur la réaction des universités lorsqu'elles répondent à la préoccupation récente concernant la qualité de l'éducation en premier cycle universitaire.

In the late 1960's and 1970's, there was a call to develop university teaching in Canada, the United States, and Great Britain (Shore, 1974; Pellino, Boburg, Blackburn, and O'Connell, 1981; Warren Piper and Glatter, 1977). Universities responded by creating centres, projects, and programs which encouraged faculty to use technology (computers, television, systematic design of instruction), to attend workshops and seminars, to apply for leave time and travel grants, and, particularly in the United States, to assess teaching (Centra, 1976; Menges and Levinson-Rose, 1980). Traditional approaches, such as becoming more knowledgeable in one's discipline, were forsaken because teaching, developed in this manner, had drawn students' criticism (Gaff, 1975). The anti-intellectual mood of the late 1960's and early 1970's also may have contributed to the search for innovative methods for developing teaching (Bergquist, 1982; Ross, 1976).

The various methods for improving teaching, first audio-visual, next instructional systems, and then faculty development, were greeted enthusiastically (Geis, 1980). However, faculty became disillusioned when none of these efforts succeeded in making important changes. Academics now are pessimistic about what can be done to transform university teaching (Rutherford, 1983).

Evidence that those attempts did not create the desired changes can be found in the continuing call for improvement in undergraduate instruction. The Association of American Colleges (1985) wants curricular reform; Shulman (1989) advocates developing a pedagogy of substance; and Watkins (1989) reports that the Higher Education Research Program believes universities must "... acknowledge 'explicitly and forcefully' that teaching and learning are their chief occupations and must support steps to improve instruction..." (p. A 13).

Although during the seventies, no widespread changes occurred in teaching in higher education, the literature describes some successful programs and centres (Sharpham, 1980; Nelson and Siegel, 1980). These were found to pay attention to instructional processes, faculty attitudes, and organizational climate because innovations need to be adopted by faculty and supported by institutions (Chait and 
Gueths, 1981). The descriptions of the programs, however, are unclear about the mixture and/or sequencing of the three components. Lindquist (1978) contends, "We must do it all" (p. 9). Warren Piper (1974) calls instructional development "muddlemuch" and Cannon (1983) wonders if it is an act of faith. Rice (1983) believes that the instrumental and methodological emphasis in developing teaching has been too narrow and suggests, "It is time to raise questions of meaning" (p. 56).

To consider what developing teaching means to academics, one program, the Ontario Universities Program for Instructional Development (OUPID), was examined in relation to what academics and universities value and, hence, wish to pursue. Lindquist (1978) attributes the strength and uniformity of these values to the faculty's socialization in graduate school, which is reinforced when they enter academic life and seek tenure.

When academics' values are probed, it is discovered that they believe research is their primary work (Shulman 1979; Neatby, 1982; Skolnik and Rowen, 1984). They hold this view even if they do no research themselves (Ladd, 1979). Although there is much talk of publishing or perishing, faculty actually do research because it interests them, not because of external pressures to publish (Finkelstein, 1984). They work, on average, 53 hours a week and feel there is not enough time to accomplish all they wish (National Center for Education Statistics, 1990; Pellino et al., 1981). Faculty understand that academic freedom, tenure, and institutional autonomy make it possible for them to teach and do research in an atmosphere of freedom (Whalley, 1964). Academic administrators, like academics, indicate a university's priority is research and that only peer review maintains. excellence (Skolnik and Rowen, 1984; Altbach, 1987).

Most faculty enjoy teaching, think they do it well, and assume teaching improves when they do research and remain current in their disciplines (Cross, 1980; Gaff, 1975). Writing a new syllabus and creating tests are other ways faculty thinks their teaching develops (Pellino et al., 1981). Although some faculty wish to use technologies in their teaching, there neither appears to be one reason nor one group of faculty who wish to do this (Light, 1990; Davis, Abedor, and Witt, 1976).

For academics, good teaching is a close association between faculty and students, and competence in one's discipline. As they teach, their goal is to enable students to learn the material and to think critically (Ontario Confederation of University Faculty Associations [OCUFA], 1979; Lowman, 1984; Bayer, 1973).

\section{Methodology}

A case study of OUPID was conducted first to examine the Program in depth and second to consider the meaning it had for faculty and their universities. The latter goal will be accomplished by considering how OUPID's methods agreed with the values held by academics and academic administrators. Guba and Lincoln (1982) state that the purpose of a case study can be factual, interpretive and evaluative. 
This study was conducted to be interpretive and hence focused on the "history, meanings, understandings and theory" (p. 374). It was unnecessary to evaluate the Program because during its operation this was done twice, first in 1975 and again in 1979.

The boundaries of a case study are difficult but important to determine (Stake, 1978). Time became the boundary - beginning with Trotter's 1970 report and ending when OUPID closed in 1980.

Data were collected through a content analysis of OUPID's documents: minutes of committee meetings, reports from OUPID to the Council of Ontario Universities (COU), the OUPID Newsletter, Annual Reports from OUPID's Directors, COU's minutes and annual reports, grant applications, reports on the grants, and the two evaluations of OUPID, one an independent evaluation (Main et al., 1975) and the second a report created by OUPID staff and a graduate student in higher education (OUPID, 1979). In addition, structured interviews were undertaken with OUPID leaders and evaluators $(\mathrm{N}=18)^{1}$ and a random sample of faculty involved with OUPID $(\mathrm{N}=12)$ to probe the findings from the documents about OUPID's origins and implementation as well as to discover perceptions of how teaching develops, what constitutes good teaching, the priorities of academics, and the relationship of teaching and research. These interview data will be included in the appropriate sections to provide depth to findings from the documents and to suggest ways OUPID either did or did not agree with the values academics hold. Guba and Lincoln (1982) indicate that collecting data in different ways from different sources facilitates checking and cross interpretation. This triangulation allows greater confidence in the findings.

Although case study methodology assumes each phenomenon is unique, it also assumes human endeavour has enough regularity that it is possible to generalize from a specific situation to ones which are similar (Eisner, 1981). This tenet holds for OUPID because its methods were similar to those used in other instructional development programs initiated in the 1970 's, i.e., small grants to individuals, grants to universities, workshops, conferences (Centra, 1976; Menges and Levinson-Rose, 1980).

OUPID's context was similar too because the Ontario universities' mandate is to teach, do research, and service (Kerr, 1972; Commission on the Future Role of Universities in Ontario, 1981). In addition, Ontario's institutions are founded on the belief that excellence in higher education is fostered by academic freedom, tenure, and institutional autonomy (Whalley, 1964). Academics and academic administrators in Ontario value research and believe it is an academic's preeminent work; teaching is secondary. These beliefs, too, are held in common with their counterparts outside Ontario (Shulman, 1979; Neatby, 1983; Skolnik and Rowan, 1984).

OUPID's designated funding from the Provincial Government was one way it differed from many programs which were supported from outside sources such as the Kellogg Foundation or the Lilly Foundation. The influence of this funding will be discussed separately to indicate how that variable affected the Program. 


\section{The Context: The Universities of Ontario}

OUPID was established as a central effort to develop teaching in all Ontario's 16 provincially funded universities. According to Government policy, a university education is accessible to all qualified applicants although each institution may determine who qualifies for its programs. The institutional autonomy which allows the universities to decide who shall be taught, extends to decisions about who teaches, what they teach, and how the operating grants are dispersed.

Although Ontario's universities are not considered a system, they are linked in a loose organizational structure comprised of the institutions themselves; a consultative body, the Council of Ontario Universities (COU), which consists of the universities' chief executive officers and their faculty colleagues; a Government ministry, the Ministry of Colleges and Universities (MCU); and the Government's advisory body, the Committee on University Affairs/Ontario Council on University Affairs (CUA/OCUA) ${ }^{2}$ (Smith, 1984). COU, MCU, and CUA/OCUA all played parts in developing teaching through this central Program.

\section{Developing Teaching: OUPID's Way}

OUPID's origins are found in a report, Television and Technology in University Teaching, written in 1970 by Bernard Trotter at the request of the Committee of Presidents of the Universities of Ontario $(\mathrm{CPOU})^{3}$ and the Committee on University Affairs (CUA). In it, he suggested a fundamental review of the universities' instructional processes and recommended establishing a Centre where faculty from the 16 institutions could learn to develop university teaching.

Although the Centre was discussed for two years by Trotter, members of COU's Secretariat, CUA, and COU, it never came into existence. The Ministry opposed it, fearing a Centre would look like its creation and not the universities'. CUA's Chairman, Dr. J. Parr, opposed it after visiting centres in the United Kingdom which he discovered were not particularly effective even though located at individual universities. He decided that one which was to serve an entire province had little hope of success (Main, et al., 1975). COU (1972) opposed it because it wanted the earmarked funding to go directly to the universities.

In the face of this opposition, the Centre, which was to provide opportunities to faculty, became a program "... to assist individual Faculty members in Ontario Universities and the Universities themselves in improving the effectiveness and efficiency of their instructional processes. ... No approach ... is regarded as outside the scope of the Program" (Main et al., 1975, p. 12).

To administer the Program, COU established a Joint COU/CUA Subcommittee which, although it changed its name over the years, Joint CUA/COU Committee on Educational Technology (1972), CUA/COU Joint Subcommittee on Instructional Development (1973), Interim Committee on Instructional Development (1974), maintained a relatively stable membership.

The Subcommittee implemented the Program by issuing yearly province-wide calls for applications to develop teaching from individual faculty or faculty teams. 
Table 1

1975 Faculty Applications: What Would Be Developed?

Undergraduate cours

Graduate course

CAI materials

Other materials (AV simulations, modules)

Research project

Remedial programs for students (5 included a research component)

Expertise in instructional development (study leaves/conferences)

Instructional development units (general faculty development)

Textbook

Community relations (town or town/gown)

Widespread changes were to occur as these individual projects created a ripple effect. This would be speeded through a publication, the OUPID Newsletter, a network of faculty who were to serve as Liaison Officers in their own universities, and various workshops, conferences, and meetings.

To understand what those faculty applying for grants thought might improve teaching, the 1975 applications were analyzed and sorted according to what would be developed (Table 1) and how it would be developed (Table 2). In most of their applications, the faculty indicated they would use several processes to develop their teaching, e.g., travel, hiring a secretary and/or a computer programmer, buying materials, etc.

Table 3 shows the various projects the Subcommittee supported in 1975. The average individual grant during this period (1973-75) was $\$ 7,350$.

Throughout the individual grants phase, the Subcommittee never articulated a vision of instructional development. Although it gave some indication of its perceptions of how teaching could be improved through its funding decisions, that signal was unclear because the group made decisions more on the basis of how well the proposal was written than on what would be accomplished. The Subcommittee's reticence arose from its fear that offering its vision would have "... given the Programme a directive role and would have prevented the Committee from identifying those projects which were likely to succeed because they demonstrated a certain grasp of fundamental instructional development principles" (Main et al., 1975, p. 19). 
Table 2

1975 Faculty Applications: How Would Instruction Be Developed?

$\begin{array}{lr}\text { Travel } & 45 \\ \text { Hire an assistant or research associate } & 30 \\ \text { Buy materials (includes postage) } & 25 \\ \text { Release time for academics to develop course } & 24 \\ \text { Hire a computer programmer - computer costs } & 21 \\ \text { Hire a graduate or undergraduate student(s) } & 15 \\ \text { Hire a secretary (part-time) } & 14 \\ \text { Hire a consultant } & 11 \\ \text { Buy AV materials } & 11 \\ \text { Make AV materials } & 7 \\ \text { Attend workshops } & 6 \\ \text { Buy equipment } & 5\end{array}$

In 1975, COU asked for an independent evaluation of the individual grants (1973-75). In their report, Main, Berland, and Morand recommended a shift to institutional grants because they thought instructional development is "... best served by local initiative with all planning and organization taking place at the individual university level ..." $(1975$, p. 54).

OUPID's institutional phase (1976-80) was administered by the COU Committee on Teaching and Learning (CTL). It believed instructional development must " $\ldots$ be absorbed into the blood stream of each campus" (CTL, July 1976). As its first initiative, CTL asked the universities to develop a clear statement of their long-term instructional development goals and include in their applications provisions for 1) an instructional development resource person or group, 2) means of communicating ideas, 3) resources for travel, and 4) a small grants program. CTL considered OUPID successful because of its "... cautious and low profile approach ..." (Parrett, 1977, p. 15). At the same time, CTL thought that the universities might not really know how to spend the money and so believed that it needed to provide help as they moved toward greater autonomy in their programs (CTL, April, 1976). Since the universities consider themselves autonomous, this might have caused some friction between them and CTL. 
Table 3

1975 Projects Funded by the Subcommittee

Remedial programs developed for students
Travel (study leaves)
. learn PSI
. study curriculum
. learn audio visual methods
. visit instructional development centres
Course Development
- curricular change (1)
. create computer assisted learning (3)
. develop distance or modulized course (4)
Instructional Development Workshops/Units
. Develop instructional development workshops (1975-76)
Course Evaluations

The 1976 applications were analyzed to determine the universities' plans for developing teaching. Table 4 reveals that each institution planned to use several methods. The average institutional grant was $\$ 26,565$.

The universities yearly submitted proposals such as those in 1976 which agreed with their understanding of CTL's guidelines. However, the Committee appeared to apply its funding criteria differently depending on its assessment of each institution's stage of instructional development expertise. It further confused the universities by anticipating the future funding a program might expect from its own institution once OUPID's support ceased and declined to "inflate" the support to the university beyond that amount (CTL, April, 1977). It also withheld monies from three universities, in the last year of funding (1979), because it determined their programs would not continue if OUPID's funding was withdrawn.

\section{OUPID'S IMPACT}

OUPID provides a unique opportunity to examine two different methods of developing teaching, an individual approach (1973-75) and an institutional 
Table 4

Universities' 1976 Proposals to Develop Instruction

$\begin{array}{lr}\text { Release faculty to coordinate ID activities } & 10 \\ \text { Sponsor instructional development workshops } & 6 \\ \text { Develop course/faculty evaluations } & 5 \\ \text { Develop remedial programs for students } & 5 \\ \text { Mini-grant program for faculty } & 4 \\ \text { Publish and distribute newsletter } & 4 \\ \text { Employ consultants } & 2 \\ \text { Buy supplies } & 2 \\ \text { Provide travel funds } & 2 \\ \text { Hire technicians or assistants } & 2 \\ \text { Do research } & 2 \\ \text { Pay for computer time } & 2 \\ \text { Provide teaching awards } & 2 \\ \text { Establish contingency fund } & 1\end{array}$

approach (1976-80). Comparing the impact of the two is difficult, however, because they were evaluated differently. The individual grants phase (1973-75) was independently evaluated at COU's request by Alex Main, an instructional developer from the UK, and Alyn Berland and Peter Morand, academics from Ontario. The evaluators found that the faculty who had received grants thought the funding had been useful although they had not evaluated their projects. Main et al. (1975) concluded that "Given the commitment and resources ... it [OUPID] has been a valuable seed ground for instructional development" (1975, p. 50). They recommended a shift to institutional grants because they believed that academics need institutional support as they develop their teaching.

Instead of an independent evaluation of institutional grants (1976-80), OUPID's Executive Director and the Chairman of the Committee on Teaching and Learning met with the Universities' Presidents and with people doing instructional development to discover their perceptions of OUPID. During these visits, they found the presidents mixed in their assessment of OUPID, although always supportive of the idea that developing teaching was important.

In addition to these visits, OUPID's staff compiled a report which, although entitled "OUPID Evaluation Project Report," was not prepared “... with the intent 
to prove OUPID had been a success but ... to learn from the program's brief history" $(1979$, p. 1). Apparently COU did not understand this because it wondered why "... the evaluation report failed to address the Programme in qualitative terms" (COU, 1979).

The report did, however, address OUPID in quantitative terms. For example, it states that grants were given in eight categories: Research 35 , General travel 18 , Specific travel 42 , Conducting instructional development workshops and seminars 97, Developing materials 106, Redesigning courses 63, Communicating information 8 , Evaluation 24 . The grants also were categorized by discipline: agriculture 3 , architecture 3, biological sciences 17 , business management 11 , cultural studies 4 , earth sciences 18 , education 5 , engineering 24 , fine arts 9 , humanities 44 , law 3 , library science 2 , mathematics 19 , medicine 23 , physical education 1 , physical sciences 25 , social work 4 , social sciences 35 , and instructional development 126 . The report further states that the grant recipients indicated that 608 professional colleagues, 144 graduate students, 379 undergraduate students, 16 research officers, 87 general support staff and 35 others had been involved in these efforts to develop teaching. The recipients also indicated that 32,907 students were “... served by OUPID sponsored projects" (p. 67).

When COU voted on OUPID's future in its March 1979 meeting, the discussion revolved around earmarked funding, not the quality or the quantity of the Program. The vote was close, 11/10, and the question went back to COU's Executive Committee which decided that greater consensus was needed if Council were to reconsider the question. OUPID closed in June, 1980.

If OUPID's goal was to develop teaching in all Ontario's universities it had limited success. For example, in its last year CTL withheld grants to three institutions because it felt they would not continue after OUPID funding ceased. The Program also did not affect many faculty. The ripple effect which was supposed to occur was slowed by the fact that in university teaching, innovations must be incorporated into each course by each professor in ways which match his or her own understanding of the discipline. The average grant to individuals was $\$ 7,350$. If each faculty member in Ontario had wanted to change his or her teaching in the ways apparently advocated by the Program, presumably each would have needed that amount of money.

However limited, OUPID did touch some faculty and some institutions. It supported and advanced several universities which had units before OUPID officially opened in 1973, e.g., Laurentian, Guelph, McMaster, Carlton. In addition, even before the institutional grants, Waterloo was in the process of developing a unit and Western had a development fund which was used for curricular change. ${ }^{4}$

\section{REASONS FOR OUPID'S LIMITED IMPACT}

The reasons for the Program's limitations were attributed to the lack of a clearly articulated plan, the amount, and the designation of the funding. These reasons 
were discerned from the two evaluations, the minutes of meetings of the Subcommittee, the Liaison officers, CTL and COU.

Although the case study was not designed to evaluate OUPID because it had been evaluated, those interviewed were asked their perception of OUPID's success, in order to determine whether they agreed or disagreed with the reasons found in the documents. Most indicated the Program had made a valuable but limited impact on teaching. The leaders/evaluators mentioned that the amount of money allocated to the Program was responsible for the limitation. They commented, "Got about as much bang for the buck as possible." "Good but spotty." "Look at the amount of money allocated - negligible." Several thought that it had a great impact on a few faculty. Although they were not too confident about the impact on the institutions, one said, "It had a stimulative effect even at [university]."

Although it is possible to explain OUPID's narrow effect on teaching by citing the lack of vision or plan and the amount and designation of the funds, it is possible also to explain its effect by considering the meaning teaching has for academics. For example, the methods OUPID appeared to advocate did not agree with academics' views of good teaching, with their understanding of how teaching improves, and the universities' conception of the way excellence is promoted. The reasons presented in the documents and the interviews will be examined first and then considered in relation to the values which give meaning to the work in which academics engage.

\section{Impact: The Lack of a Plan}

Apparently, OUPID's plan was to avoid having a plan because the Program was experimental and "... ideas needed to evolve in response to the felt needs of the faculty and the university and in relation to experience" (COU, 1975). A leader/evaluator explained, "OUPID had no plan. It was hoped, not unreasonably, that if something got started, something might be learned."

When asked about OUPID's beginnings, the interviewees recalled: "People wondered how the new technologies might assist learning." "There was a general feeling that not enough thought was going into teaching." "Remember, this was a time of student unrest: The universities needed to make a commitment, needed to take the initiative." "The Ministry began OUPID over the head of COU; it keeps a pocket of money with which it can do that. The idea was to seed something institutionalized." "Not much of a plan." "We thought, 'Let's get going'."

While the lack of direction might make it appear that faculty could develop teaching in any way they might like, which would agree with the idea that they must decide what to teach and how to teach, actually it created problems because faculty wondered what kinds of proposals to submit, the Liaison Officers were confused about their function, and the Subcommittee itself asked why the proposals did not reflect an understanding of instructional development (Main et al., 1975; Interim Committee, 1975). 
During the institutional grants phase, CTL thought it was taking a low-keyed approach to developing teaching. However, as it funded some programs and not others and some projects within the proposals, it actually was directive while still not presenting any image of excellent teaching or of a program which would foster that teaching.

\section{Impact: Designated Funding}

Another reason for OUPID's limited impact was the tension created by its earmarked funding. In the planning stage, COU argued that the money should go to the institutions because they understood their own situations and priorities. Nevertheless, in 1972, COU accepted the idea for the Program because "... there was agreement that a systematic attempt to catalyze development in this area is needed."

After the 1975 evaluation, COU again expressed its concern about the funding and Parrett (1976) remarked that " $\ldots$ the debate during 1975-January 1976 cast some soubt [sic] as to whether the universities would accept the policy of earmarked funds ..." (p. 23). Again, at the March meeting when COU discussed OUPID's future, the debate concerned earmarked funding.

In the interviews, the leaders/evaluators were equivocal in their assessment of the designated funding's effect on the Program. Although they believed it was the Government's way of encouraging the universities to think seriously about improving teaching, they also believed it eroded institutional autonomy, adding that autonomy preserves academic freedom. Some wondered, however, whether the earmarked funding would have been a problem if OUPID had been more successful. One leader/evaluator even said the universities were not required to apply for the earmarked funds but added, "Earmarked funding confuses the initiatives of the institutions. If money is available, the universities will want to get some."

When considering the designation of the funding, it is necessary to ask why the Government, which funds the universities on the basis of student numbers, decided to earmark additional funds for teaching improvements. The reason most likely stems from the priority of research, because "Under a financing system such as Ontario's, research must affect teaching ... [since] support for research does not occur here as a direct money subsidy, but in large part as a transfer of faculty time" (Smith, 1972, p. 53).

Seen in this light, it is possible to think of the designated funding as the Government's mechanism for alerting the universities to the fact that teaching needed more attention. As one leader/evaluator remarked, "The universities say they are the best judge of their priorities but if they had judged their priorities better there would have been no need for the earmarked funds."

COU states that OUPID began in "... an atmosphere of mixed interest, scepticism, and opposition" (1976, p. 36). Although some of this distrust can be attributed to the earmarked funding, there is evidence that it also can be traced to a 
lack of confidence in the Program's ability to develop teaching. COU, for example, thought the wrong faculty would apply for the money and this was one reason it wanted the money to go to the institutions (COU, November, 1972). During the individual grants period, the Liaison Officers expressed concern that the faculty applying for funds were interested only in the money and had little understanding of OUPID's purpose (Liaison Officers, May 2-3, 1974). When the grants went to institutions, the Liaison Officers wondered if their own universities were ready to use the money wisely (Interim Committee, 1975) and CTL, too, questioned whether the universities really knew how to spend money to improve teaching and consequently "... felt the need for a transition toward greater institutional autonomy rather than a sudden jump" (CTL, April, 1976).

\section{Limited Impact: Money}

Between 1973 and 1980, OUPID received $\$ 2,500,000$ : $\$ 250,000$ (1973-74), $\$ 350,000$ (1974-75), $\$ 350,000$ (1975-76), $\$ 500,000$ (1976-77), $\$ 500,000$ $(1977-78)^{5}, \$ 350,000(1978-79), \$ 200,000(1979-80)$. The funds were limited. Main et al. (1975) thought this as they recommended OUPID receive $1 \%$ of the total universities' budget. CTL thought this and requested additional funding. The Subcommittee and CTL continually mentioned the limitation the amount of funding put on the grants they were able to make. In the interviews, the leader/evaluators indicated that this small amount of money had limited OUPID's influence on teaching.

Earmarked or not, the funds focused attention on teaching. As the faculty, who received individual grants, indicated in the interviews, "The funds gave teaching improvement credibility." "Money crossing university boundaries has a stimulating effect." "We have funding for research; we need funding for teaching."

The institutional grants were also positive because they created a focus in the universities for developing teaching. A faculty member who helped write the institutional grant recalled, "It did make the central administration think about instruction. It brought together people interested in teaching and they interested others."

Although it could be argued endlessly that more money would have produced more improvements, it is useful to remember that most faculty in Ontario never applied to OUPID for funding. There are approximately 12,800 faculty in Ontario (Statistics Canada, 1980). Although it is possible to state that 259 faculty applied for grants during the individual phase (1973-75), the numbers are more difficult to determine for the institutional phase since the universities were remiss in sending annual reports (six interim and eight final reports were submitted between 1976-1978). However, in 1978, OUPID sent evaluation questionnaires to 400 grant recipients (1973-78) and 210 unsuccessful applicants for the years 1973-78.

Additional supporting evidence for the view that most academics do not consider money necessary when developing teaching comes from a Faculty 
Fellows Program implemented for one year in the mid-1970's by an Ontario University. The Program gave 40 faculty each a grant of $\$ 500$ to continue to develop their teaching. Twelve of the 40 spent none of their money and 11 others did not spend the full amount. Those who partially or fully spent their grants did so on buying equipment (screens, slide projectors), travelling, and hiring an assistant or computer programmer.

The universities, too, did not always find it easy to spend money on developing teaching; in 1977-78, nine institutions returned a total of $\$ 22,921.25$ to the Ministry. ${ }^{6}$ The amounts ranged from $\$ 253.38$ to $\$ 18,344.18$.

\section{OUPID: Questions and Issues Not Addressed}

Not only did OUPID's methods disagree with the values many faculty hold, the Program ignored several issues and questions which are central to university teaching. For example, it never examined the ideal of the relationship of teaching and research (Jaspers, 1960; Whitehead, 1959). If this means excellent researchers are also excellent teachers there is little evidence to support this ideal (Friedrick and Michalak, 1983). However, university mission statements proclaim the relationship and most faculty consider it important. Support for this belief was found in comments made in the interviews.

Those interviewed commented, "Research must be paramount in the university, otherwise we are doomed to teach only what we were taught. I would hate to see teaching and research separated." Others suggested, "Few people who do not get involved with research have the ability to renew their teaching." "The justification of the university is that teaching and research contribute positively to one another."

In avoiding the question of how teaching and research are linked, OUPID was not alone. Other programs initiated in this period also failed to explore how faculty think teaching and research inform one another (Centra, 1976; Geis, 1980).

OUPID's methods also did not agree with the faculty's idea that teaching develops when they learn more about their disciplines (Gaff, 1975). No funding was given to support this activity. Even the study leaves, which might have provided that opportunity, were granted to individuals to learn about instructional development, not about their disciplines. In addition, the emphasis on the use of technology did not reflect faculty's image of good teaching since it appears to distance them from their students.

The Program also failed to address the question of research's preeminence in the universities. To determine whether this issue was not addressed because those involved in the Program did not hold the same values, the interviewees were asked their perception of the universities' priorities. Twenty-five said "research." Of the five who did not, two said, "Research and teaching are equal," and the others said, "It is unproductive to consider which has priority."

Since the value accorded research is translated into institutional rewards for faculty, there is much thought that if teaching received greater rewards, more time would be spent on it and it would then improve (Smith, 1984; Association of 
American Colleges, 1985). OUPID did not address the issue of rewards for teaching even though the faculty attending "Priorities' 74," an OUPID-sponsored conference organized to set the Program's direction, indicated this was important (COU, 1975). Main et al. (1975), too, were concerned about rewards for teaching and declared that "As long as the activity of research is considered more important for career advancement and immediate return than that of teaching, any programme that directs itself to encouraging individuals to alter their approach to teaching is unlikely to have great success" (p. 50).

OUPID was silent, too, on the question of teaching excellence or what teaching would be like when it improved. To gather perceptions of good teaching, the interviewees were asked to describe it. The responses ranged: "Have a real command of the subject matter," "Someone at the cutting edge," "Enthusiasm for the field," "Verbal talent," "One needs to articulate ideas and have a sensitivity to students," "The student needs to become excited about the subject and whatever does that is good teaching," "Professors have to have something to say, otherwise teaching becomes trivialized." These images of teaching, as a close association of faculty and their students at the cutting edge of a discipline, are found also in the 1979 OCUFA citations for the teaching awards it gives annually (Ontario Confederation of University Faculty Associations, 1979).

\section{Developing Teaching by Extending the Definition of the University}

Bennis (1976) suggests that if changes are to be made in universities those involved must know "... when an idea is antithetical to the values of an academic institution and when it extends the definition of a university and makes it more viable" (p. 224). OUPID did not take this approach. Its methods exemplify Mackenzie, Eraut, and Jones' comment that first attempts to develop teaching are "... practical rather than intellectual" and consequently leave the "... central assumptions about the teaching-learning process largely unchallenged ..." $(1970$, pp. 1-2).

Although faculty hold a vision of teaching excellence which rests on their desire to imbue students with the vitality of a discipline, this way of teaching often eludes them in their classrooms. Recent reports by the Association of American Colleges (1985), the National Institution of Education (1984), and research (Entwistle, 1984; Scott, 1985) all find teaching to be content-driven. Gardner characterizes this way of teaching as "... handing students cut flowers and forbidding them to see the growing plants" (Arons, 1985, p. 31).

Recent trends in developing teaching appear to reflect more closely academic values. Light (1990) discusses how Harvard is examining and improving its programs. The approach that university has taken emphasises collegiality and the importance of engaging in and reflecting on the process of changing teaching.

Another promising idea is that of Boyer and Rice (Rice, 1990) who believe the definition of scholarship needs to be extended. Although they accept that advancing knowledge is one aspect of scholarship, integrating, applying, and 
representing knowledge also need to be considered scholarly activities. All those forms of scholarship can be brought into one's teaching. Elrick, Jenkinson, and Thomas (1990) report a curricular change which used a team approach to interdisciplinary teaching. The dialogue and review in which the faculty engaged as they planned and taught the courses were found to be beneficial to their teaching.

\section{CONCLUSIONS}

OUPID, and other efforts to develop teaching initiated in the 1970's, neither built on the faculty's vision of good teaching nor on their understanding that engaging in research improves teaching. The methods used by OUPID and other programs, accepted the view that teaching would improve if new methods were employed, particularly those using technology.

Although methodological and instrumental approaches can be helpful, programs like OUPID which relied on them were bound to have a limited impact because they never confronted the questions and issues which are believed to impede excellence, for example, teaching's low priority, the lack of collegial review of teaching, and the subsequent lack of rewards.

OUPID carried an additional burden because its earmarked funding made COU continually wary of this intervention into an activity central to the universities' mandate.

By ignoring academic traditions and values, programs like OUPID were constantly at odds with powerful forces within the universities. What can be learned from OUPID, and programs like it, is that attempts to develop teaching must agree with and extend academic values if they are to make widespread changes in university teaching.

\section{REFERENCES}

Abedor, A., \& Sachs, S. (1978). The relationship betwen faculty development (FD) organizational development (OD) and instructional development (ID): Readiness for instructional development in higher education. In R. Bass and D. B. Lumsden (Eds.), Instructional development: The state of the art (pp. 1-19). Columbus, OH: Collegiate Publishing Inc.

Altbach, P. (1987). The knowledge context. New York, NY: State University of New York Press.

Arons, A.B. (1985, October 18-19). Conceptual difficulties of science. In M. Rice (Ed.), Undergraduate education in chemistry and physics, Proceedings of the Chicago Conference on Liberal Education. Chicago, IL.

Association of American Colleges. (1985). Integrity in the college curriculum: A report to the academic community. Washington, DC: Author.

Bayer, A.E. (1973). Teaching faculty in academe. 1972-73 ACE Research Reports, 8(2). Washington, DC: American Council on Education.

Bennis, W. (1976). Who sank the yellow submarine? In W. Bennis, K. Benne, R. Chen, \& K. Corey (Eds.), The planning of change (pp. 219-227). New York, NY: Holt Reinhart and Winston.

Bergquist, W. (1982, October 14). Faculty development under fire: Perspective and some proposals. Paper presented at the Professional and Organization Development Conference, Montebello, PQ. 
Cannon, R. (1983). The professional development of Australian university teachers: An act of faith? Higher Education, 12, 19-33.

Centra, J.A. (1976). Faculty development practice in U.S. colleges and universities. Princeton, NJ: Educational Testing Service.

Chait, R., \& Gueths, J. (1981). A framework for faculty development. Change, 13(14), 30-33.

Commission on the Future Role of Universities in Ontario. (1981). The report on the future role of universities in Ontario. Toronto, Ont: Ministry of Colleges and Universities.

Committee on Teaching and Learning. (1976, December). [Minutes of meeting]. Unpublished raw data.

Committee on Teaching and Learning. (1976, April). [Minutes of meeting]. Unpublished raw data.

Committee on Teaching and Learning. (1976, July). [Minutes of meeting]. Unpublished raw data.

Committee on Teaching and Learning. (1977, April). [Letter to a university.] Unpublished raw data.

Council of Ontario Universities. (1972, November). [Memorandum to Subcommittee on Educational Technology]. Unpublished raw data.

Council of Ontario Universities. (1975). New structure new environment. Toronto, Ont: Author.

Council of Ontario Universities. (1975, November). [Minutes of meeting]. Unpublished raw data.

Council of Ontario Universities. (1979, January). [Minutes of meeting]. Unpublished raw data.

Cross, K.P. (1980, April). Not can, but will college training be improved? Reflections, pp. 1-11.

Davis, R., Abedor, A., \& Witt, P. (1976). Commitment to excellence. East Lansing, MI: Michigan State University.

Eisner, E. (1981, April 5-9). On the difference between scientific and artistic approaches to qualitative research. Educational Researcher.

Elrick, R.M., Jenkinson, G.M., \& Thomas, R.L. (1990). Student and faculty perceptions of curricular change. Journal of Agronomic Education, 19(1), 21-24.

Entwistle, N. (1984). Contrasting perspectives on learning. In F. Marton, D. Hounsell, N. Entwistle (Eds.), The experience of learning. Edinburgh, GB: Scottish Academic Press.

Finkelstein, M. (1984). The American academic profession. Columbus: $\mathrm{OH}$ : Ohio State University Press.

Friedrick, R.J., \& Michalak, Jr., S.J. (1983). Why doesn't research improve teaching? Journal of Higher Education, 54(2), 145-163.

Gaff, J.G. (1975). Toward faculty renewal. San Francisco, CA: Jossey-Bass.

Geis, G. (1980). On instructional systems developers being useful. In D. Rhodes \& D. Hounsell (Eds.), Staff development for the 1980's, (pp. 113-132). Normal, IL: Illinois State University Foundation.

Guba, E.G., \& Lincoln, Y.S. (1981). Effective evaluation. San Francisco, CA: Jossey-Bass.

Interim Committee on Instructional Development. (1975, January). [Minutes of meeting]. Unpublished raw data.

Jaspers, K. (1960). The idea of the university. London, GB: Peter Owen.

Joint CUA/COU Subcommittee on Educational Technology. (1972, November). [Minutes of Meeting]. Unpublished raw data.

Joint CUA/COU Subcommittee on Instructional Development. (1974). Draft budget and rationale.

Kerr, C. (1972). The uses of the university (rev. ed.). Cambridge, MA: Harvard University Press.

Ladd, E.C. Jr. (1979). The work experience of American college professors: Some data on an argument. Current Issues in Higher Education, 2, 3-12.

Liaison Officers. (1974, May 2-3). [Minutes of meeting]. Unpublished raw data.

Light, R.J. (1990). The Harvard assessment seminars. Cambridge, MA: Harvard University.

Lindquist, J. (1978). Strategies for change. Berkeley, CA: Pacific Sounding Press.

Lowman, J. (1984). Mastering the techniques of teaching. San Francisco, CA: Jossey-Bass.

Main, A., Berland, A., \& Morand, P. (1975). Teaching and learning. Toronto, Ont: Council of Ontario Universities.

MacKenzie, N., Eraut, M., \& Jones, H.C. (1970). Teaching and learning. Paris, FR: UNESCO. 
Menges, R.J., \& Levinson-Rose, J. (1980, April 7-11). Why research tells us so little about interventions to improve college teaching. Paper presented at the Annual Meeting of the American Educational Research Association, Boston, MA.

National Center for Education Statistics. (1990). Faculty in Higher Education Institutions, 1989. US Department of Education.

National Institute of Education's Study Group on the Conditions of Excellence. (1984). Involvement in learning: Realizing the potential of America's higher education, Chronicle of Higher Education, 29(9), 35-49.

Neatby, J.B. (1982). The gospel of research: The transformation of English-Canadian universities. Transactions of the Royal Society of Canada, 20(4), 275-284.

Nelsen, W., \& Siegel, M. (Eds). (1980). Effective approaches to faculty development. Washington, DC: Association of American Colleges.

Ontario Confederation of University Faculty Association. (1979). [Citations for 1979 Teaching Awards]. Unpublished raw data.

Ontario Universities Program for Instructional Development. (1979). Evaluation report. Toronto, Ont: Author.

Parrett, F. (1976). Ontario Universities Programme for Instructional Development: Annual report. Toronto, Ont: OUPID.

Parrett, F. (1977). Ontario Universities Programme for Instructional Development: Annual report. Toronto, Ont: OUPID.

Pellino, G., Blackburn, R., Boberg, A., \& O'Connell, C. (1981). Planning and evaluating professional growth programs for faculty. Ann Arbor, MI: Michigan State University Centre for the Study of Higher Education.

Rice, E. (1983). Being professional academically. In D. Bedsole (Ed.), Critical aspects of faculty development programs. Sherman, TX: Austin College.

Rice, E. (1990). Rethinking what it means to be a scholar. Teaching Professor, 4(14), 1-2.

Ross, M. (1976). The university. New York, NY: McGraw-Hill Book Company.

Rutherford, D. (1983). [Review of The Management of Peer Group Learning]. Higher Education, 12(5), 627.

Scott, C. (1985, March 31-April 4). Discrepancies between curricula and desired learning outcome. Paper presented at the Annual Meeting of the American Educational Research Association, Chicago, IL.

Sharpham, J. (1980). Staff in staff development. In D. Rhodes \& D. Hounsell (Eds.). Staff development for the 1980's (pp. 133-146). Normal, IL: Illinois State University Foundation.

Shore, B. (1974). Instructional development in Canadian higher education. Canadian Journal of Higher Education, 4(2), 45-53.

Shulman, C. (1979). Old expectations, new realities: The academic profession revisited. (ERIC AAHE Report No. 2). Washington, DC: American Association for Higher Education.

Shulman, L. (1989). Toward a pedagogy of substance. AAHE Bulletin, 4l(10), 8-13.

Skolnik, M., \& Rowen, N. (1984). Please sir, I want some more. Toronto, Ont: Ontario Institute for Studies in Education Press.

Smith, A. (1972). The production of scientific knowledge in Ontario universities. Toronto, Ont: Queens Printer, W. Kinmond.

Smith, J.P. (1984). Tidy minds, untidy solutions: University organization in Ontario. Higher Education, 13, 569-581.

Smith, R.A. (1984). Faculty perception of teaching improvement. Unpublished doctoral dissertation, McGill University, Montreal, PQ.

Stake, R. (1978, February). The case study method of social inquiry. Educational Researcher, pp. 5-8.

Statistics Canada. (1980). Teachers in universities. Ottawa, Ont: Ministry of Supply and Services.

Trotter, B. (1970). Television and technology in university teaching. Toronto, Ont: T.H. Best Printing Co. 
Warren Piper, D. (1974). Muddlemuch: Staff development in universities. In W.A. Verreck (Ed.)., Methodological problems in research and development in higher education (pp. 143-160). Amsterdam, Neth: Swets and Zeitlinger.

Warren Piper, D., \& Glatter, R. (1977). The changing university. Windsor, Ont: NFER Publishing Co. Ltd.

Watkins, B.T. (1989, April 26). Colleges urged to avow that teaching is central to their mission and to take steps to upgrade it. The Chronicle of Education, p. A13.

Whalley, G. (Ed.). (1964). A place of liberty. Toronto, Ont: Clarke Irwin.

Whitehead, A.N. (1959). The aims of education and other essays. New York, NY: The MacMillian Co.

\section{NOTES}

1 The interview data from OUPID's leaders and evaluators were combined to protect confidentiality.

2 CUA was the predecessor of the Ontario Council of Universities Affairs (OCUA). The change occurred in 1974.

3 CPUO was COU's predecessor. The change occurred in 1971.

4 Although the boundaries of the study were the years 1970-1980, it is heartening to note that several institutions continuously have maintained units devoted to developing teaching, e.g., McMaster, Waterloo, Guelph, Western, York, Ottawa. Wilfrid Laurier has just re-established a unit, at Toronto an individual faculty member has recently been seconded part-time to be the Provost's Advisor on Undergraduate Education. In addition, the creation of the Society for Teaching and Learning in Higher Education (STLHE), a national organization devoted to improving the quality of instruction, is a direct result of the connections established between Western, Guelph, Waterloo, and McMaster during OUPID which continued after it closed.

5 OUPID received an additional year of funding through the intervention of CTL. It asked the Minister, the Honourable Harry Parrot, for more time and he accepted the recommendation, allocating $\$ 500,000$ for that purpose.

6 Since the funds were earmarked, they had to be returned if unused for teaching development. 